\title{
Evidencia de transferencia horizontal de genes de resistencia a antibióticos provenientes de bacterias ambientales
}

\author{
Patricio A. Valencia C. ${ }^{1 *}$, Verónica Barragán ${ }^{1}$, Gabriel A. Trueba P. ${ }^{1}$ \\ ${ }^{1}$ Colegio de Ciencias Biológicas y Ambientales, Universidad San Francisco de Quito \\ Diego de Robles y Vía Interoceánica, Quito, Ecuador \\ *Autor principal/Corresponding author, e-mail: pv86@hotmail.com. \\ Editado por/Edited by: S. Zapata, M.Sc. \\ Recibido/Received: 02/09/2010. Aceptado/Accepted: 04/01/2010. \\ Publicado en línea/Published on Web: 05/25/2010. Impreso/Printed: 06/01/2010.
}

\begin{abstract}
This study looked for the presence of environmental antibiotic resistance genes and their capacity to disseminate through conjugation. Water and soil samples were collected from pristine zones of the Ecuadorian Amazon Basin (Sucumbíos, Napo and Orellana provinces), and they were inoculated in a modify wheat grain medium (WGM). Some of WGM cultures contained diverse bacterial species that were able to transfer antibiotic resistance genes to Escherichia coli K12. Finally, 10 strains were isolated and proved to be responsible of antibiotic resistance gene transfer. Strains were identified (using 16S rDNA sequences) as Serratia sp., Pseudomonas sp., Listonella sp., and Aeromonas sp. In this work, we proved that environmental bacteria can transfer antibiotic resistance genes as tetraciclin and ampicilin.
\end{abstract}

Keywords. Conjugation, horizontal gen transfer, antibiotic resistance genes, environmental bacteria.

\section{Resumen}

El presente estudio exploró la presencia y la capacidad de diseminación de genes de resistencia a antibióticos provenientes de bacterias ambientales. Se recolectó muestras de agua y suelo de zonas prístinas de la Amazonía ecuatoriana (provincias de Sucumbíos, Napo y Orellana) las cuales fueron inoculadas en un medio de grano de trigo modificado (WGM). Algunos de estos cultivos multi-bacterianos (mixtos) demostraron tener bacterias capaces de transferir genes de resistencia a antibióticos a una cepa de Escherichia coli K12. A partir de los cultivos mixtos se aisló 10 cepas bacterianas responsables de esta transferencia. Las cepas aisladas fueron identificadas mediante el secuenciamiento del gen del ARN ribosomal 16S (16S rDNA) como Serratia sp., Pseudomonas sp., Listonella sp. y Aeromonas sp. El hallazgo más importante del presente trabajo fue el probar que existe transferencia de genes que proveen resistencia a antibióticos como la tetraciclina y ampicilina a partir de bacterias ambientales.

Palabras Clave. Conjugación, transferencia horizontal de genes, genes de resistencia a antibióticos, bacterias ambientales.

\section{Introducción}

La existencia de una amplia diversidad de bacterias resistentes a antibióticos ha sido relacionada con el uso masivo de estos fármacos en el tratamiento de infecciones y en prácticas de ganadería. Sin embargo, los genes de resistencia a antibióticos están presentes en bacterias que pululan en ríos y suelos de zonas remotas, lejanas a la actividad humana. Más aún, el medio ambiente probablemente fue el escenario natural donde se originaron y evolucionaron estos genes [1]. Existe evidencia de que estos genes han evolucionado y se han diversificado antes de la llamada era de los antibióti- cos [2]. Los antibióticos por lo general son producidos por miembros de comunidades microbianas ambientales complejas, muchos antibióticos actúan como un medio de comunicación química entre bacterias. Otros antibióticos sirven para eliminar la competencia por nutrientes. Las bacterias del suelo y de los ríos han estado expuestas a antibióticos por miles de millones de años y han evolucionado genes que codifican mecanismos de protección (genes de resistencia a antibióticos). La colonización y urbanización de bosques remotos no solo expone a la humanidad a nuevas enfermedades tropicales sino a nuevos genes de resistencia a antibióticos [3]. El propósito de esta investigación fue identificar genes de 
resistencia a antibióticos provenientes de bacterias ambientales capaces de ser transferidos a bacterias de la microbiota intestinal humana (E. coli).

\section{Materiales y métodos}

\section{Recolección de muestras:}

Diez muestras de agua y suelo fueron tomadas de las regiones de Saladero, Tena y Papallacta (Provincia de Napo), Aguas Negras, Lago Agrio (Provincia de Sucumbíos) y Tiputini (Provincia de Orellana). Las muestras fueron transportadas a temperatura ambiente.

\section{Tamizaje de poblaciones bacterianas con genes de re- sistencia a antibióticos}

Se preparó medio grano de trigo modificado (WGM) para lo cual se tomó 5 gramos de suelo, se lo colocó en 8 ml de agua destilada (en un tubo de cristal), se añadió un grano de trigo y se sometió a esterilización por autoclave. Luego, se adicionó 2 gramos de cada muestra de suelo ó $1 \mathrm{ml}$ de muestra de agua a un tubo con $8 \mathrm{ml}$ de WGM y se cultivó a temperatura ambiente entre 2 a 3 semanas en presencia de luz blanca. Cada una de las muestras de agua y suelo sembradas en medio WGM se denominaron cultivos mixtos. Un mililitro del cultivo mixto en medio WGM fue colocado en un tubo con $4 \mathrm{ml}$ de caldo BHI y se incubó durante 24 horas a $37^{\circ} \mathrm{C}$.

Para la conjugación se añadió al tubo del cultivo mixto (en BHI) un volumen similar de caldo BHI en el que se cultivó ( 24 horas a $37^{\circ} \mathrm{C}$ ) la cepa receptora E. coli k12 resistente a ácido nalidíxico (K12RAN). Finalmente se tomó 100ul del caldo de conjugación y se lo extendió en dos tipos de medios: A) placas agar nutritivo con ácido nalidíxico $(15 \mathrm{ug} / \mathrm{ml})$ y ampicilina $(50 \mathrm{ug} / \mathrm{ml})$ y B) agar nutritivo con ácido nalidíxico $(15 \mathrm{ug} / \mathrm{ml})$ y tetraciclina (12 ug/ml). Todas las colonias que crecieron en los medios con antibióticos identificadas como E. coli (transconjugados) fueron seleccionadas, cultivadas y almacenadas en congelación.

Aquellos cultivos mixtos a partir de los cuales se obtuvo crecimiento de transconjugados en los medios A y B fueron utilizados para aislar cepas individuales capaces de transferir resistencia a antibióticos.

\section{Identificación de bacterias donadoras}

Los cultivos mixtos en WGM con bacterias donadoras de genes de resistencia a antibióticos fueron extendidos en dos tipos de placas petri: (i) agar nutitivo mas ampicilina $(50 \mu \mathrm{g} / \mathrm{ml})$ y (ii) agar nutritivo mas tetraciclina $(12 \mu \mathrm{g} / \mathrm{ml})$. Cada colonia aislada fue sembrada en un tubo con $4 \mathrm{ml}$ de caldo BHI e incubada por 24 horas a $37{ }^{\circ} \mathrm{C}$. Para la conjugación se añadió al tubo del cultivo mixto (en BHI) un volumen similar de caldo BHI en el que se cultivó ( 24 horas a $37^{\circ} \mathrm{C}$ ) la cepa receptora $E$. coli $\mathrm{K} 12 \mathrm{RAN}$.

\begin{tabular}{cc}
\hline Localidad de Colección & Blast Highest Hit \\
\hline Aguas Negras & Serratia marcensces strain RS25 \\
Tiputini & Pseudomonas aeruginosa strain LCB52 \\
Tiputini & Listonella anguillarum strain MHK12 \\
Tiputini & Serratia marcensces strain RI42 \\
Lago Agrio & Serratia nematodiphila strain P36 \\
Lago Agrio & Serratia marcensces strain RS25 \\
Lago Agrio & Serratia marcensces strain RI42 \\
Tena & Aeromonas sp. A33 \\
Aguas Negras & Serratia marcensces strain RS25 \\
Tiputini & Serratia marcensces strain RI42 \\
\hline
\end{tabular}

Tabla 1: Sitios de aislamiento y Blast Highest Hit de las cepas ambientales que mostraron capacidad para transferir resistencia a ampicilina o tetraciclina hacia $E$. coli K12RN.

Se tomó $100 u$ de cada caldo de conjugación y se lo extendió en dos tipos de medios: A) y B) según se describió previamente. La capacidad de cada bacteria aislada para transferir genes fue determinada mediante conjugación. Las colonias bacterianas capaces de transferir genes fueron cultivadas individualmente y sometidas a congelación.

Para la identificación genética de las bacterias capaces de trasnferir genes de resistencia a antibóticos, se extrajo ADN utilizando CTAB (CTAB 2\%, NaCl $1.4 \mathrm{M}$, EDTA $20 \mathrm{mM} \mathrm{pH} \mathrm{8,} \mathrm{HCl} 100 \mathrm{mM} \mathrm{pH} \mathrm{8).} \mathrm{Posteriormen-}$ te se amplificó la región V3 del rDNA 16S utilizando los primers 16SV3f (5'-CTACGGGAGGCAGCAG-3') y 16SV3r (5'-ATTACCGCGGTGCTGG-3'), esta región corresponde a la posición 341 - 534 en E. coli. [4] Para la amplificación se utilizó $1.5 \mathrm{mM}$ de $\mathrm{MgCl}_{2}, 0.3 \mathrm{uM}$ de cada primer, $200 \mu \mathrm{M}$ de dNTP's y $1 \mathrm{U}$ de Taq polimerasa. Las condiciones programadas en el termociclador para la PCR fueron las siguientes: desnaturalización inicial a $94{ }^{\circ} \mathrm{C}$ (4 minutos), seguida de 30 ciclos de amplificación a $94{ }^{\circ} \mathrm{C}$ durante 30 segundos para la desnaturación, $55^{\circ} \mathrm{C}$ (1 minuto) para alinear los primers, elongación a $72{ }^{\circ} \mathrm{C}$ durante 30 segundos y una extensión final a $72{ }^{\circ} \mathrm{C}$ durante 20 minutos. Los amplicones fueron enviados a MACROGEN (Corea del Sur) para el secuenciamiento y las secuencias fueron posteriomente analizadas e identificadas utilizando el programa en red, BLAST (Basic Local Alignment Search Tool).

\section{Resultados y Discusión}

\section{Tamizaje de poblaciones bacterianas con genes de re-} sistencia a antibióticos

De los cultivos mixtos en WGM provenientes de las 10 muestras recolectadas, 8 (1A, 2A, 3A, 3T, 4A, 4T, 5A y 5T) generaron transconjugados resistentes a antibioticos y presentaron resistencia a ampicilina (75\%) y a tetraciclina $(25 \%)$.

\section{Identificación de cepas donadoras}

Se amplificó un segmento de 200 pb perteneciente a la región 16s rDNA en cada una de las 10 cepas ambientales aisladas utilizando los primers 16SV3f y $16 \mathrm{SV} 3 \mathrm{r}$. El Blast Highest Hit para las secuencias correspondientes a cada una de las 10 cepas ambientales se muestra en la Tabla 1, y corespondieron a los géneros Serratia, Pseudomonas, Listonella y Aeromonas. 
En el presente estudio se identificó bacterias ambientales de la región Amazónica ecuatoriana capaces de transferir genes de resistencia a ampicilina y tetraciclina a $E$. coli. El método utilizado demostró ser eficiente para evidenciar la presencia de genes de resistencia a antibióticos de origen ambiental. Este estudio corrobora los resultados de otras investigaciones realizadas en regiones remotas del mundo como Alaska [5]. Se ha intentado sin éxito amplificar las secuencias de los genes de resistencia a ampicilia provenientes de la Amazonía utilizando primers TEMf y TEMr (que amplifican una amplia variedad de beta lactamasas). Esta observación sugiere que estos genes son distintos a los previamente descritos. No obstante con el fin de confirmar este hecho es necesaria la caracterización de los genes capturados durante el estudio [6]. Hasta donde hemos podido indagar, esta investigación muestra por primera vez el fenómeno de transferencia horizontal de genes de resistencia a antibióticos a partir de bacterias ambientales aisladas en zonas prístinas de la Amazonía ecuatoriana. Los hallazgos generados en este estudio nos permitirán continuar con estudios similares que ayuden a conocer más sobre el origen y la evolución de los genes que codifican para la resistencia a antibióticos.

\section{Agradecimientos}

Al Instituto de Microbiología de la USFQ por el financiamiento de este proyecto. A Daysi Parrales por toda su ayuda.

\section{Referencias}

[1] Allen, K. 2009. Functional metagenomics reveals diverse beta lactamases in a remote Alaskan soil. ISME Journal. 3, 243-251.

[2] Bustos, E. 1985. Transferencia plasmidial de multirresistencias en cepas enteropatogénicas de E. coli. Revista Chilena de Pediatría. 56, 445-449.

[3] Correa, G. 2008. Impacto de la resistencia a los antibióticos en el desarrollo de la medicina contemporánea. $R e$ vista Médica. 16, 9-10.

[4] Gérvas, J. 2000. La resistencia a los antibióticos un problema de salud pública. Atención Primaria. 25, 589-596.

[5] Hall, B. 2004. Predicting the evolution of antibiotic resistance genes. Nature. 2, 430-435.

[6] Jorgen, J. 2005. Ribosomal DNA sequencing. APMIS. $113,621-628$. 